\title{
BDNF Val66Met Impairs Fluoxetine-Induced Enhancement of Adult Hippocampus Plasticity
}

\author{
Kevin G Bath*,1,2, Deqiang Q Jing', Iva Dincheva', Christine C Neeb', Siobhan S Pattwell', Moses V Chao ${ }^{3}$, \\ Francis $S$ Lee $^{*, 1,4}$ and Ipe Ninan*,5 \\ 'Department of Psychiatry, Weill Medical College of Cornell, New York, NY, USA; ²Department of Neuroscience, Brown University, Providence, RI, \\ USA; ${ }^{3}$ Department of Cell Biology, Physiology and Neuroscience, and Psychiatry, The Helen L. and Martin S. Kimmel Center for Biology and \\ Medicine at the Skirball Institute for Biomolecular Medicine, New York University School of Medicine, New York, NY, USA; ${ }^{4}$ Department of \\ Pharmacology, Weill Medical College of Cornell, New York, NY, USA; ${ }^{5}$ Department of Psychiatry, New York University School of Medicine, \\ New York, NY, USA
}

\begin{abstract}
Recently, a single-nucleotide polymorphism (SNP) in the brain-derived neurotrophic factor (BDNF) gene (BDNF Val66Met) has been linked to the development of multiple forms of neuropsychiatric illness. This SNP, when genetically introduced into mice, recapitulates core phenotypes identified in human BDNF Val66Met carriers. In mice, this SNP also leads to elevated expression of anxiety-like behaviors that are not rescued with the prototypic selective serotonin reuptake inhibitor (SSRI), fluoxetine. A prominent hypothesis is that SSRIinduced augmentation of BDNF protein expression and the beneficial trophic effects of BDNF on neural plasticity are critical components for drug response. Thus, these mice represent a potential model to study the biological mechanism underlying treatment-resistant forms of affective disorders. To test whether the BDNF Val66Met SNP alters SSRI-induced changes in neural plasticity, we used wild-type $\left(\mathrm{BDNF}^{\mathrm{Val} / \mathrm{Nal}}\right.$ ) mice, and mice homozygous for the BDNF Val66Met SNP (BDNF ${ }^{\text {Met/Met }}$ ). We assessed hippocampal BDNF protein levels, survival rates of adult born cells, and synaptic plasticity (long-term potentiation, LTP) in the dentate gyrus either with or without chronic (28-day) fluoxetine treatment. BDNF ${ }^{\text {Met/Met }}$ mice had decreased basal BDNF protein levels in the hippocampus that did not significantly increase following fluoxetine treatment. BDNF ${ }^{\text {Met/Met }}$ mice had impaired survival of newly born cells and LTP in the dentate gyrus; the LTP effects remained blunted following fluoxetine treatment. The observed effects of the BDNF Val66Met SNP on hippocampal BDNF expression and synaptic plasticity provide a possible mechanistic basis by which this common BDNF SNP may impair efficacy of SSRI drug treatment.

Neuropsychopharmacology (2012) 37, 1297-1304; doi:10.1038/npp.201 1.318; published online 4 January 2012
\end{abstract}

Keywords: BDNF Val66Met SNP; hippocampus; neurogenesis; plasticity; fluoxetine; LTP

\section{INTRODUCTION}

Brain-derived neurotrophic factor (BDNF) is a critical regulator of activity-dependent plasticity in the adult brain (Barde et al., 1987; Huang and Reichardt, 2001; Chao, 2003). Genetic or environmental factors that disrupt BDNF expression or signaling have been associated with the development of a number of neuropsychiatric disorders, including major depression (Okada et al., 2006; Gatt et al.,

*Correspondence: Dr FS Lee, Department of Psychiatry, Weill Medical College of Cornell University, Weill Cornell Medical College, I300 York Avenue (LC-905), Box 244, New York, NY I002 I, USA, Tel: + I 212746 5403, Fax: + I 212746 8529, E-mail: fslee@med.cornell.edu or Dr I Ninan, Department of Psychiatry, New York University School of Medicine, 540 IAve, SKI 5-3, New York NY I00 I6, USA, Tel: + I 347535 07। 0, Fax: + I 212263 0723, E-mail: Ipe@Ninan.nyumc.org or Dr KG Bath, Department of Neuroscience, Brown University, 185 Meeting Street, Providence, RI 02916, USA, Tel: + I 40I 863 I054, E-mail: Kevin_Bath@Brown.edu

Received 5 August 2011; revised 28 October 2011; accepted 17 November 2011
2009; Verhagen et al., 2010). In rodent models, nearly all antidepressant regimens tested to date increase BDNF within the adult hippocampus (Duman and Monteggia, 2006; Musazzi et al., 2009), a brain region heavily implicated in the expression of anxiety and depressive-like symptoms (Sahay and Hen, 2007). In rodents, the genetic ablation of BDNF leads to a blockade in the response to standard antidepressant regimens (Monteggia et al., 2004; Adachi et al., 2008). Furthermore, the infusion of BDNF protein into the brains of rodents has antidepressant effects (Siuciak et al., 1997; Shirayama et al., 2002). This has led some to propose that augmentation of BDNF expression via chronic antidepressant treatment, and the subsequent trophic effects of BDNF on neural plasticity, may be one of the critical mechanisms underlying antidepressant response.

The neurotrophic hypothesis of antidepressant response has become particularly relevant given the recent discovery of a uniquely human single-nucleotide polymorphism (SNP) in the BDNF gene (BDNF Val66Met; Egan et al., 2003). This SNP leads to a nucleotide change from $G$ to $A$ at 
position 196 and subsequent amino acid change at position 66 in the BDNF prodomain, from valine to methionine, and interferes with the trafficking of BDNF mRNA (Chiaruttini et al., 2009), as well as a selective impairment in the activitydependent release of BDNF (Egan et al., 2003; Chen et al., 2004, 2005, 2006). Human carriers of this SNP have impairments in hippocampus-dependent memories and the extinction of learned fear (Egan et al., 2003; Soliman et al., 2010). Male BDNF Val66Met carriers have been shown to be at increased risk to develop depression, an effect that has recently been confirmed by the largest meta-analysis to date (Verhagen et al., 2010). In addition, carriers of the BDNF Val66Met SNP that develop depression often demonstrate more severe symptoms than individuals who are non-carriers (Hwang et al., 2006; Iga et al., 2007; Sarchiapone et al., 2008; Verhagen et al., 2010). Despite these findings, significant questions remain regarding the mechanisms underlying BDNF's contribution to the development of affective disorders and the potential role of this SNP in treatment response (Tsai et al., 2010). Animal models have provided a fruitful testing ground to address such questions.

We have generated a mouse model in which we knockedin the BDNF Val66Met SNP into the mouse bdnf gene, replacing the endogenous BDNF. Mice homozygous for the BDNF Val66Met SNP (BDNF ${ }^{\text {Met/Met }}$ ) phenocopy human SNP carriers (Chen et al., 2006; Soliman et al., 2010) and have elevated expression of anxiety-like behaviors that are unresponsive to chronic treatment with the selective serotonin reuptake inhibitor (SSRI) fluoxetine. Thus, this mouse may provide a model system to gain insights into the mechanisms by which BDNF Val66Met suppresses the response of some individuals to SSRI treatment.

In animal models of depression, two of the potential targets of increased trophic support are through augmentation of hippocampal neurogenesis (Castren, 2004; Sahay and Hen, 2007; Schmidt and Duman, 2007) and synaptic plasticity (Manji et al., 2003; Castren, 2004; Russo-Neustadt and Chen, 2005; Wang et al., 2008), both processes are impacted by altered BDNF levels (Figurov et al., 1996; Sairanen et al., 2005; Scharfman et al., 2005; Chan et al., 2008; Donovan et al., 2008; Li et al., 2008). We found that $\mathrm{BDNF}^{\mathrm{Met} / \mathrm{Met}}$ mice had decreased basal levels of BDNF in the hippocampus, and unlike $\mathrm{BDNF}^{\mathrm{Val} / \mathrm{Val}}$ mice, $\mathrm{BDNF}$ protein levels did not increase following chronic fluoxetine treatment. We tested for alterations in the functional plasticity of the hippocampus under basal conditions and following chronic fluoxetine treatment in $\mathrm{BDNF}^{\mathrm{Met} / \mathrm{Met}}$ and $\mathrm{BDNF}^{\mathrm{Val} / \mathrm{Val}}$ mice. $\mathrm{BDNF}^{\mathrm{Met} / \mathrm{Met}}$ mice also had fewer surviving newly born cells in the adult dentate gyrus (DG) of the hippocampus relative to $\mathrm{BDNF}^{\mathrm{Val} / \mathrm{Val}}$ controls. Following fluoxetine treatment, neurogenesis in $\mathrm{BDNF}^{\mathrm{Met} / \mathrm{Met}}$ mice normalized to untreated wildtype levels. Finally, we found impairments in long-term potentiation (LTP) in the DG of $\mathrm{BDNF}^{\mathrm{Met} / \mathrm{Met}}$ mice compared with $\mathrm{BDNF}^{\mathrm{Val} / \mathrm{Val}}$ controls, an effect that was not rescued by chronic fluoxetine treatment. These studies are the first to identify impairments in BDNF protein expression, the incorporation of newly born cells, and synaptic plasticity in the DG of adult BDNF ${ }^{\text {Met/Met }}$ mice. Furthermore, these studies provide a possible mechanistic framework through which the BDNF Val66Met SNP could impair SSRI response.

\section{MATERIALS AND METHODS}

\section{Mice}

All mice used in these studies were adult males (3-4 months of age), housed in standard shoebox cages on a 12:12 reverse light/dark schedule. BDNF knockout mice as described in (Lyons et al., 1999) and TrkB knockout mice as described in (Klein et al., 1989) along with wild-type littermate controls were also used for cell survival studies. For the remainder of studies, BDNF Val66Met knock-in mice $\left(\mathrm{BDNF}^{\mathrm{Met} / \mathrm{Met}}\right)$ and wild-type $\left(\mathrm{BDNF}^{\mathrm{Val} / \mathrm{Val}}\right)$ littermate controls as described in (Chen et al., 2006) were used. All mouse lines were fully backcrossed (minimum of 10 generations) onto an inbred C57BL/6 background. Animal care was in accordance with Weill Medical College of Cornell University IACUC and FDA standards.

\section{Tissue Preparation and Immunohistochemistry}

Control and genetically modified lines of mice were deeply anesthetized with pentobarbital and transcardially perfused with a solution of $0.9 \%$ saline and $0.1 \%$ sodium nitrite followed by $4 \%$ paraformaldehyde in phosphate buffer. Brains were dissected out and postfixed in $4 \%$ paraformadehyde for $1 \mathrm{~h}$. Brains were then incubated in a $30 \%$ sucrose solution overnight at $4{ }^{\circ} \mathrm{C}$. Coronal sections were serially cut at $40 \mu \mathrm{m}$ using a freezing microtome. Immunohistochemistry was performed on floating sections. Briefly, sections were first incubated in a blocking solution for $1 \mathrm{~h}$ and then transferred to the primary antibody solution for $48 \mathrm{~h}$ at $4{ }^{\circ} \mathrm{C}$ before incubation with the corresponding fluorescentlabeled (Invitrogen, Carlsbad, CA) or biotinylated secondary antibody (Vector Laboratories, Burlingame, CA). Antibodies and dilutions used included a rabbit polyclonal anti-pTrkB (1:500), anti-NeuN (Millipore; 1:1000), antipolysialylated neural cell adhesion molecule (PSA-NCAM; Millipore; 1:400), anti-GFAP (Millipore; 1:1000), antiBrdU (BD Biosciences; $1: 200$ ). BrdU-labeled sections were analyzed using a standard Nikon (Tokyo, Japan) upright microscope, digital camera mount, and the MetaMorph software package (Molecular Devices, Sunnyvale, CA). For co-labeling studies we performed confocal fluorescence microscopy using a Zeiss (Oberkochen, Germany) LSM510 microscope fitted with a Zeiss $\times 631.4$ numerical aperture objective with standard filter sets and a standard (1 Airy disk) pinhole.

\section{Fluoxetine Administration}

Fluoxetine was dissolved in water $(160 \mathrm{mg} / \mathrm{l}$, as described in (Dulawa et al., 2004)) and administered in light-protected water bottles. Fluoxetine infused water was changed every $72 \mathrm{~h}$ to insure fresh and active drug. Inclusion of fluoxetine led to no change in water consumption, and based on the average daily water intake of mice $(3.1 \mathrm{ml}$ per mouse, per day with a range of $2.5-3.8 \mathrm{ml}$ ), this concentration led to an average daily dose of $0.5 \mathrm{mg}$ of fluoxetine per day (or $\sim 16 \mathrm{mg} / \mathrm{kg}$ ). This dosing regimen has been shown to lead to therapeutic levels in blood and to be highly effective in reducing anxiety-like symptoms in standard inbred mouse strains (Dulwala et al., 2004; Dulwala and Hen, 2005). 


\section{BDNF ELISA}

To measure endogenous BDNF levels, a BDNF enzymelinked immunosorbent assay (ELISA) was used (BDNF Emax Immunoassay System, Promega, Madison, WI) with recombinant BDNF as a standard. This methodology demonstrates low cross-reactivity $(<3 \%)$ with other neurotrophic factors and is capable of detecting a minimum of $15.6 \mathrm{pg} / \mathrm{ml}$ of BDNF. Briefly, control and fluoxetine treated $\mathrm{BDNF}^{\mathrm{Val} / \mathrm{Val}}$ and $\mathrm{BDNF}^{\mathrm{Met} / \mathrm{Met}}$ mice were killed by cervical dislocation and then decapitation. Brains were collected on ice and total bilateral hippocampi were dissected and then lysed in $700 \mu \mathrm{l}$ TNE lysis buffer $(0.1 \mathrm{M}$ Tris $\mathrm{HCl}, 0.15 \mathrm{M} \mathrm{NaCl}, 0.001 \mathrm{M}$ EDTA, $1 \% \mathrm{NP}-40$ ). Lysates were centrifuged for $10 \mathrm{~min}$ at $4^{\circ} \mathrm{C}$ and the clarified supernatant was collected. Using the Bradford method, total levels of protein were quantified. Tissue and assay were prepared and run in accordance with the manufacturers suggested protocol. BDNF levels were then corrected based on the total amount of protein loaded.

\section{BrdU Labeling, Detection, and Quantification}

BrdU labeling and immunohistochemcial detection was carried out as described in Bath et al. (2008). To quantify the density of BrdU positive cells in the sub-granular \& granule cell layer of the DG, a profile counting method was used (described below). To estimate the rate of survival of newly born cells, mice were given a single injection of $\mathrm{BrdU}$ $(160 \mathrm{mg} / \mathrm{kg})$ and allowed to survive for 4 -weeks prior to sacrifice. To avoid double counting, every third serially obtained section ( $80 \mu \mathrm{m}$ interval) and was counterstained with Nissl to allow discrimination of individual cells that may be clustered. All BrdU-positive nuclei within the granule cell layer of the DG were counted. The total number of counted cells was then divided into the total volume measured in order to obtain an estimate of the density of BrdU positive cells within this structure.

\section{LTP and Basal Transmission in DG}

Control or fluoxetine treated mice were killed by decapitation after pentobarbital anesthesia. Brains were quickly removed and placed in ice-cold artificial cerebrospinal fluid (ACSF) consisting of (in $\mathrm{mM}$ ): $\mathrm{NaCl}(118), \mathrm{KCl}(4.4), \mathrm{CaCl}_{2}$ (2), $\mathrm{MgCl}_{2}$ (2), $\mathrm{NaHCO}_{3}(26), \mathrm{NaH}_{2} \mathrm{PO}_{4}$ (1), D-glucose (10) aerated by $95 \% \mathrm{O}_{2} / 5 \% \mathrm{CO}_{2}$ (pH 7.4; Ninan et al., 2010). Hippocampi were quickly removed. Transverse hippocampal slices $(400 \mu \mathrm{m})$ were cut and transferred to a slice preincubator (Scientific System Design, Canada) at room temperature for at least 1-h to allow for recovery. A single slice was then transferred to an interface-recording chamber maintained at $32{ }^{\circ} \mathrm{C}$ (Scientific System Design, Canada). The chamber was continuously perfused by ACSF at a constant rate of $2 \mathrm{ml} / \mathrm{min}$. Recording electrodes were filled with $2 \mathrm{M}$ $\mathrm{NaCl}$ solution and field excitatory postsynaptic potentials (fEPSPs) were recorded from the molecular layer of the DG with IE-210 amplifier (Warner Instruments, USA) using Digidata $1440 \mathrm{~A}$ and pClamp 10 software (Molecular Devices, USA). The stimulating electrode (concentric bipolar electrodes, FHC, Bowdoinham, ME) was placed in the medial perforant path (MPP) and stimulated using a
Digital stimulator PG4000A (Cygnus Technology, PA) and stimulus isolator A365 (World Precision Instruments, Sarasota, FL). MPP-DG pathway was confirmed by assessing paired-pulse depression (PPD) at $50 \mathrm{~ms}$ inter-pulse interval (McNaughton, 1980; Wang et al., 2008). After obtaining stable basal recording, input-output curves were generated. A 15-minute baseline was recorded every $20 \mathrm{~s}$ at an intensity that evoked a response approximately $35 \%$ of the maximum evoked response. LTP was induced using $100 \mathrm{~Hz}$ stimulation ( 4 trains, $100 \mathrm{~Hz}$ for $1 \mathrm{~min}$, separated by $20 \mathrm{~s}$ ). Responses were recorded for $1 \mathrm{~h}$ after tetanization and measured fEPSP slope expressed as percentage of baseline.

\section{Statistics}

For comparisons in which greater than two groups were included, a one-way analysis of variance (ANOVA) was used. In the event of a significant main effect, post hoc group comparisons were made using a least significant differences (LSD) approach, correcting for multiple tests. In cases in which two-groups were compared, we used Student's $t$-test. For all statistics $\alpha$-value was set at $<0.05$. SPSS software (IBM) was used for all analyses.

\section{RESULTS}

\section{Chronic Fluoxetine Fails to Normalize Hippocampal BDNF Levels in BDNF ${ }^{\text {Met/Met }}$ Mice}

In rodent models, nearly all antidepressant regimens tested to date have been shown to increase BDNF protein levels in the hippocampus and other brain regions (Duman and Monteggia, 2006), an effect implicated in antidepressant efficacy. To test if the BDNF Val66Met polymorphism affects basal or SSRI-related augmentation of hippocampal BDNF protein levels in mice, we used a BDNF ELISA. We found a significant main effect of group (ANOVA, $\left.\mathrm{F}_{(3,35)}=6.058, p<0.002\right)$. More specifically, we found that $\mathrm{BDNF}$ protein levels in untreated $\mathrm{BDNF}^{\text {Met/Met }}$ mice were significantly lower than that observed in untreated wildtype $\left(\mathrm{BDNF}^{\mathrm{Val} / \mathrm{Val}}\right)$ mice (post hoc LSD, $p<0.01$; Figure 1 ). As anticipated, following 28-days of fluoxetine treatment,

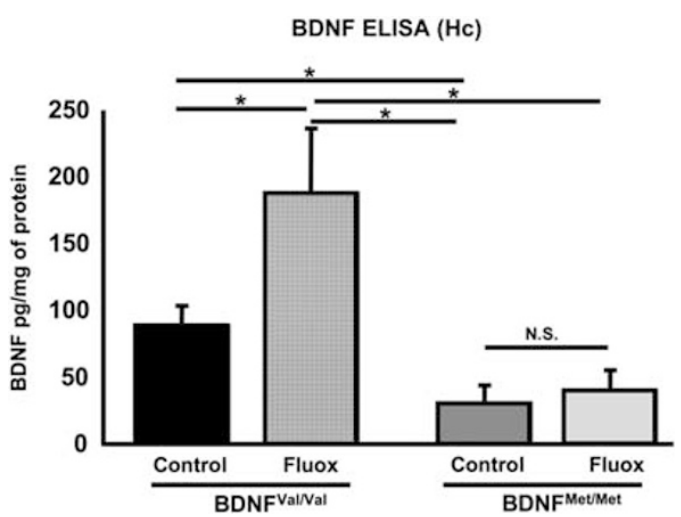

Figure I Bar graphs depicting BDNF protein levels ( $\mathrm{pg} / \mathrm{mg}$ of protein) in hippocampal lysates from adult wild-type (control $n=1 \mid$, fluox $n=1 \mid$; $\mathrm{BDNF} \mathrm{Val}^{\mathrm{Val}}$ ) and BDNF Val66Met homozygous (control $n=9$, fluox $n=1 \mathrm{I}$; BDNF ${ }^{\text {Met/Met }}$ ) mice maintained for 28 days on water (Control) or $160 \mathrm{mg} / \mathrm{l}$ fluoxetine (Fluox); * indicates significant difference, $p<0.05$. N.S., not significant difference. 
$\mathrm{BDNF}^{\mathrm{Val} / \mathrm{Val}}$ mice showed a significant increase in BDNF protein levels compared with untreated $\mathrm{BDNF}^{\mathrm{Val} / \mathrm{Val}}$ controls (post hoc LSD, $p<0.01$; Figure 1). Interestingly, fluoxetine treatment did not increase BDNF protein expression in $\mathrm{BDNF}^{\mathrm{Met} / \mathrm{Met}}$ mice above levels observed in untreated BDNF ${ }^{\text {Met/Met }}$ controls (post hoc LSD, $p>0.05$ ) and remained significantly lower than that observed in untreated $\mathrm{BDNF}^{\mathrm{Val} / \mathrm{Val}}$ mice (post hoc LSD, $p<0.05$ ).

\section{Altered BDNF and TrkB Expression Decrease Basal Rates of Cell Survival in the Adult DG}

In previous reports, the genetic ablation of BDNF or TrkB in mice leads to a selective loss of surviving newly born but not proliferating cells of the DG (Bergami et al., 2008; Chan et al., 2008; Bergami et al., 2009; Gao and Chen, 2009). Furthermore, during neurogenesis, the BDNF receptor, TrkB, is selectively expressed by postmitotic neuroblasts and neurons (Donovan et al., 2008). The loss of BDNF alters the neuronal fate of these cells and leads to decreased dendritic complexity of differentiated DG neurons (Chan et al., 2008). Using immunohistochemical labeling for the phosphorylated form of $\operatorname{TrkB}$ ( $\mathrm{pTrkB}$ ), we found $\mathrm{p} \operatorname{TrkB}$ to be most highly expressed on immature (PSA-NCAMpositive) neuroblasts (Bath et al., 2008). In the rostral migratory stream $\mathrm{pTrkB}$ expression was not detectable on GFAP-positive or NeuN-positive cells (Bath et al., 2008). These effects were identical to what we observed in the DG (Supplementary Figure 1). On the basis on these observations, we focused our investigation of BDNF-mediated effects following fluoxetine treatment upon measures of cell survival within the DG.

We used BrdU labeling (Supplementary Figure 2) to test if altered BDNF or TrkB expression impacts the survival of newly born cells of the adult DG. Consistent with previous reports (Sairanen et al., 2005; Chan et al., 2008), the density of BrdU-positive cells in the DG of heterozygous BDNF knock-out mice $\left(\mathrm{BDNF}^{+/-}\right)$was significantly lower than that observed in wild-type littermate controls $\left(\mathrm{BDNF}^{+/+}\right.$; Student's $t$-test, $t(6)=5.74, p<0.01$; Figure $2 \mathrm{a})$. Similarly, genetic ablation of one copy of the trkb gene $\left(\operatorname{TrkB}^{+/-}\right)$ resulted in a significant reduction in the density of surviving newly born granule cells in the DG (Student's $t$ test, $t(6)=2.44, p<0.05$; Figure $2 \mathrm{~b}$ ) compared with wildtype littermate controls $\left(\operatorname{TrkB}{ }^{+/+}\right)$. For mice in which the
BDNF Val66Met SNP was genetically knocked-in, we found a main effect of genotype (ANOVA, $\mathrm{F}_{(2,9)}=2.939, p<0.05$; see Supplementary Figure 3); BDNF $^{\text {Met/Met }}$ mice had a significant reduction in the density of surviving BrdUlabeled cells compared with $\mathrm{BDNF}^{\mathrm{Val} / \mathrm{Val}}$ mice (Post Hoc LSD, $p<0.05$; Figure 2c).

\section{Impact of Chronic Fluoxetine on Cell Survival in the DG} of $\mathrm{BDNF}^{\text {Met/Met }}$ Mice

Chronic antidepressant treatment has been shown to augment the survival of newly born cells in the adult DG (Castren, 2004). To test whether the BDNF Val66Met polymorphism altered the antidepressant-induced increase in cell survival, we again used BrdU labeling to track cell survival. We found a significant main effect of group (ANOVA, $\mathrm{F}_{(3,20)}=6.257, p<0.01$; Figure 3 ). We noted a significant difference in basal rates of neurogenesis between $\mathrm{BDNF}^{\mathrm{Val} / \mathrm{Val}}$ and $\mathrm{BDNF}^{\mathrm{Met} / \mathrm{Met}}$ mice, with $\mathrm{BDNF}^{\mathrm{Met} / \mathrm{Met}}$ mice having fewer surviving BrdU-positive cells (post hoc LSD, $p<0.05)$. Chronic fluoxetine led to a significant increase in the survival of newly born cells in both $\mathrm{BDNF}^{\mathrm{Val} / \mathrm{Val}}$ (post hoc LSD, $p<0.05$ ) and $\mathrm{BDNF}^{\mathrm{Met} / \mathrm{Met}}$ mice (post hoc LSD, $p<0.05)$ compared with untreated control groups.

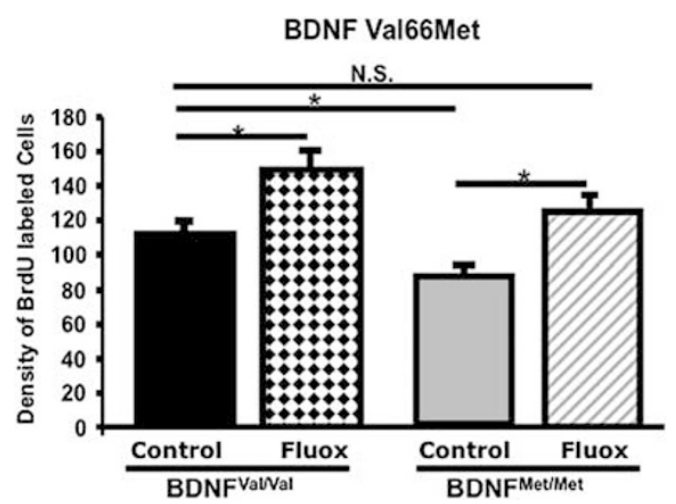

Figure 3 Bar graphs depicting BrdU cell density (cells $/ \mathrm{mm}^{3}$ ) in the DG of adult mice 28 days following BrdU administration in the DG adult $\mathrm{BDNF}^{\mathrm{Val} / \mathrm{Val}}$ ( $n=6$ per group) and $\mathrm{BDNF}^{\text {Met/Met }}(n=6$ per group) mice maintained for 28 days on water (Control) or $160 \mathrm{mg} / \mathrm{l}$ fluoxetine (Fluox); * indicates significant difference, $p<0.05$. N.S., not significant difference.
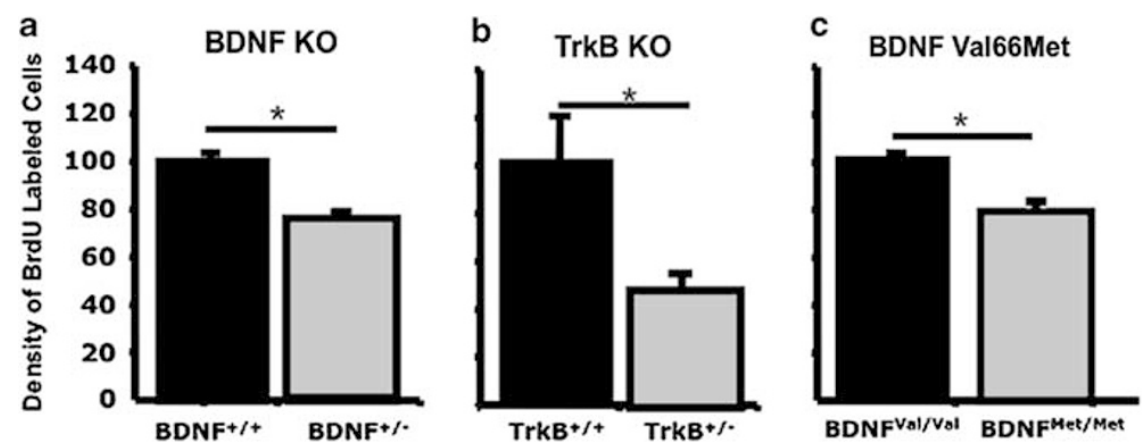

Figure 2 Bar graphs depicting BrdU cell density (cells $/ \mathrm{mm}^{3}$ ) in the dentate gyrus of adult mice 28 days following BrdU injection in (a) BDNF wild-type $\left(n=4 ; \mathrm{BDNF}^{+/+}\right)$and BDNF heterozygous $\left(n=4 ; \mathrm{BDNF}^{+/-}\right)$mice, (b) TrkB wild-type $\left(n=4 ; \operatorname{TrkB}^{+/+}\right)$and TrkB heterozygous $\left(n=4 ;\right.$ TrkB $\left.{ }^{+/-}\right)$mice. $\mathrm{BrdU}$ cell density $\left(\mathrm{cell} / \mathrm{s} / \mathrm{mm}^{3}\right)(\mathrm{c})$ in BDNF ${ }^{\mathrm{Val} / \mathrm{Nal}}(n=5)$ and BDNF ${ }^{\text {Met Met }}(n=5)$ mice; ${ }^{*}$ indicates significant difference, $p<0.05$. 
BDNF $^{\text {Met/Met }}$ Impairs Synaptic Plasticity Within the Dentate Gyrus

Earlier studies have demonstrated that chronic fluoxetine treatment can enhance synaptic neurotransmission and plasticity in the DG (Wang et al., 2008). We tested whether the BDNF Val66Met polymorphism interfered with the fluoxetine-induced enhancement of synaptic transmission (fEPSP) and synaptic plasticity (LTP) in the DG. We analyzed PPD to confirm the MPP-DG pathway and to determine whether this short-term plasticity was modified by the BDNF Val66Met polymorphism or fluoxetine treatment (McNaughton, 1980; Wang et al., 2008). Although we did not observe a difference in PPD between $\mathrm{BDNF}^{\mathrm{Met} / \mathrm{Met}}$ and $\mathrm{BDNF}^{\mathrm{Val} / \mathrm{Val}}$ mice, fluoxetine treatment decreased PPD in BDNF ${ }^{\mathrm{Val} / \mathrm{Val}}$ mice (ANOVA followed by post hoc comparison, $p<0.05$, Figure $4 \mathrm{a}$ ). Our results are consistent with the earlier report that chronic fluoxetine decreased PPD at the MPP-DG synapses and this effect might be independent of neurogenesis (Wang et al., 2008). However, the suppression of PPD in fluoxetine-treated BDNF $^{\text {Met/Met }}$ did not reach statistical significance (ANOVA followed by post hoc comparison, $p>0.05$ ). Input-output relationship analysis of fEPSP slope revealed no significant differences in basal synaptic neurotransmission between untreated $\mathrm{BDNF}^{\mathrm{Met} / \mathrm{Met}}$ and matched $\mathrm{BDNF}^{\mathrm{Val} / \mathrm{Val}}$ mice (Two-way ANOVA, $p>0.05$, Figure 4b). Although fluoxetine treatment induced a robust enhancement of basal synaptic neurotransmission in the $\mathrm{BDNF}^{\mathrm{Val} / \mathrm{Val}}$ mice (Twoway ANOVA, $\mathrm{F}_{(1,14)}=14.5, p<0.01$, Figure $4 \mathrm{~b}$ ), fluoxetinetreated BDNF ${ }^{\text {Met/Met }}$ mice revealed a slight but statistically nonsignificant enhancement of basal synaptic neurotransmission compared with the untreated mice $(p>0.05$, Figure $4 \mathrm{~b})$. As the long-lasting potentiation in the MPP-DG pathway in the absence of GABA blockers is sensitive to the incorporation of new cells into the hippocampus (Snyder et al., 2001; Saxe et al., 2006; Wang et al., 2008), we hypothesized that impaired survival of newly a

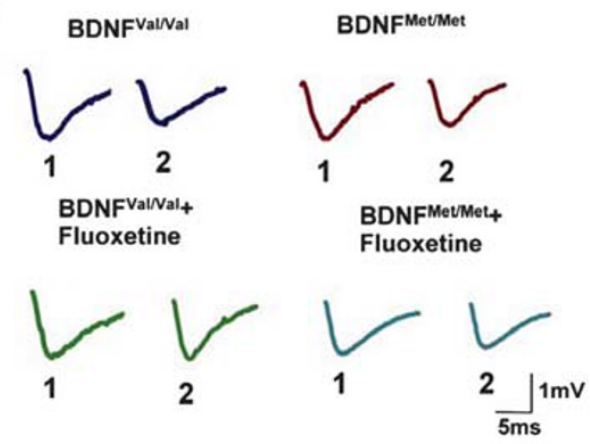

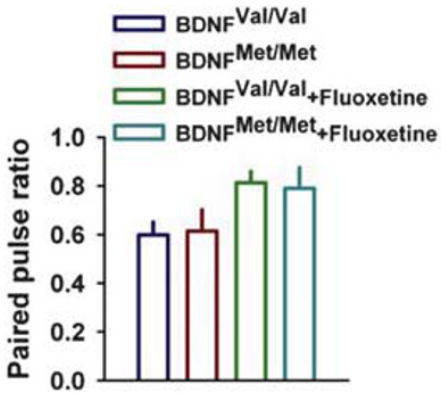

b

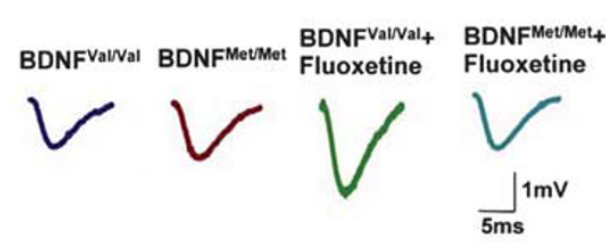

c

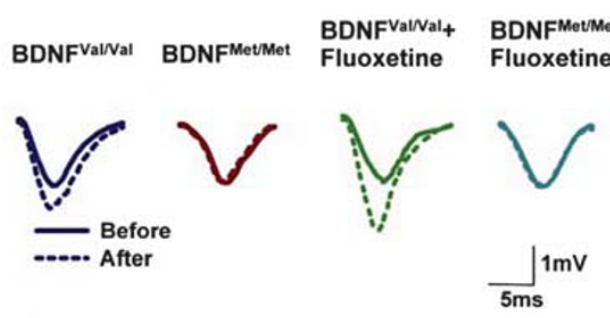

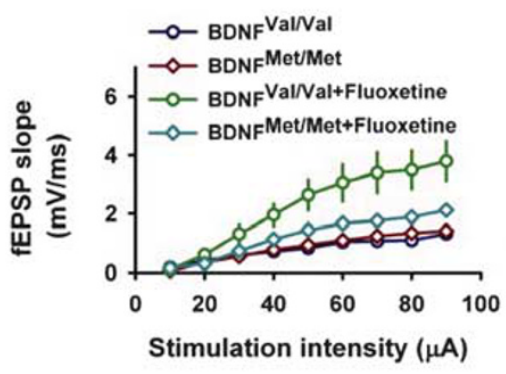

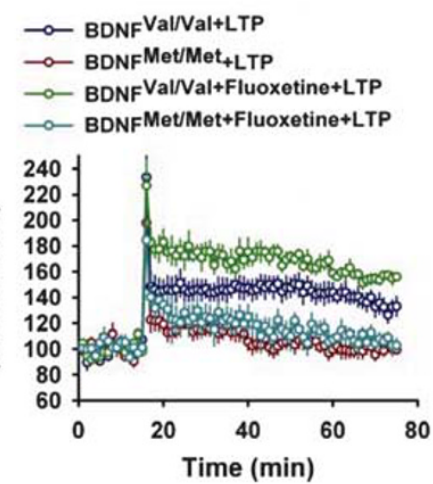

Figure 4 Effect of fluoxetine treatment on synaptic neurotransmission and plasticity in the DG. (a) PPD of fEPSPs in BDNF $F^{\mathrm{Val} / \mathrm{Nal}}(n=10)$, BDNF ${ }^{\mathrm{Met} / \mathrm{Met}}$ $(n=8)$, fluoxetine $+\mathrm{BDNF}^{\mathrm{Val} / \mathrm{Val}}(n=10)$ and fluoxetine $+\mathrm{BDNF}^{\text {Met/Met }}$ groups $(n=8)$. Fluoxetine treatment suppressed the PPD in BDNF ${ }^{\mathrm{val} / \mathrm{Val}}$ mice but not in BDNFMet/Met mice. (b) Input-output curves of fEPSPs in BDNF Val/Val $(n=10)$, BDNF Met/Met $(n=8)$, fluoxetine + BDNF Bal/Val $^{(}(n=10)$ and fluoxetine + BDNF $^{\text {Met/Met }}$ groups $(n=8)$. Fluoxetine treatment induced a robust enhancement of basal synaptic neurotransmission in the BDNF ${ }^{\mathrm{Val} / \mathrm{Val}}$ mice but not in

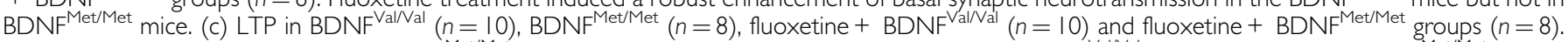
LTP was significantly impaired in the BDNF Met/Met mice. Fluoxetine selectively enhanced LTP in the BDNF ${ }^{\text {Val/Nal }}$ mice but not in the BDNF ${ }^{\text {Met/Met }}$ mice. 
born cells in the $\mathrm{BDNF}^{\mathrm{Met} / \mathrm{Met}}$ mice could interfere with fluoxetine-induced enhancement of long-lasting potentiation in the MPP-DG pathway. Consistent with the earlier reports (Snyder et al., 2001; Saxe et al., 2006; Wang et al., 2008), application of a $100 \mathrm{~Hz}$ stimulus (4 trains, $100 \mathrm{~Hz}$ for $1 \mathrm{~min}$, separated by $20 \mathrm{~s}$ ) induced long-lasting potentiation in the untreated $\mathrm{BDNF}^{\mathrm{Val} / \mathrm{Val}}$ mice (Figure 4c). However, the long-lasting potentiation in the $\mathrm{BDNF}^{\mathrm{Met} / \mathrm{Met}}$ mice was significantly lower than that observed in $\mathrm{BDNF}^{\mathrm{Val} / \mathrm{Val}}$ mice (Two-way ANOVA, $\mathrm{F}_{(1,16)}=24.4, p<0.01$, Figure 4c). Although fluoxetine treatment significantly enhanced longlasting potentiation in the $\mathrm{BDNF}^{\mathrm{Val} / \mathrm{Val}}$ mice (Two-way ANOVA, $\mathrm{F}_{(1,18)}=8.6, p<0.01$, Figure $\left.4 \mathrm{c}\right)$, the $\mathrm{BDNF}^{\text {Met/Met }}$ mice did not show any significant improvement in longlasting potentiation after fluoxetine treatment compared with untreated BDNF ${ }^{\text {Met/Met }}$ controls (Two-way ANOVA, $p>0.05$, Figure $4 c$ ).

\section{DISCUSSION}

In this report, we provide the first mechanistic links between the BDNF Val66Met polymorphism and SSRI drug resistance. We found that $\mathrm{BDNF}^{\mathrm{Met} / \mathrm{Met}}$ mice had decreased basal levels of hippocampal BDNF and did not show antidepressant-induced augmentation of BDNF protein levels. BDNF ${ }^{\text {Met/Met }}$ mice had impairments in the survival of newly born cells in the DG, an effect that was normalized to control wild-type levels by SSRI treatment. Finally, we observed a blunting of synaptic plasticity within the DG of $\mathrm{BDNF}^{\mathrm{Met} / \mathrm{Met}}$ mice, an effect that could not be rescued with the SSRI fluoxetine. These studies identify several potential mechanisms underlying blunted treatment response in mice that are homozygous for the BDNF Val66Met SNP, and may have implications for understanding mechanisms underlying treatment non-responsiveness in human populations.

Under baseline conditions, BDNF ${ }^{\text {Met/Met }}$ mice had significantly lower BDNF protein levels in the hippocampus compared with control $\mathrm{BDNF}^{\mathrm{Val} / \mathrm{Val}}$ mice. In previous reports, we have shown that the BDNF Val66Met SNP does not lead to a reduction in total BDNF levels in the whole brain of $\mathrm{BDNF}^{\mathrm{Met} / \mathrm{Met}}$ mice, cultured cortical neurons from $\mathrm{BDNF}^{\mathrm{Met} / \mathrm{Met}}$ mice (Chen et al., 2006), or cortical tissues (Bath et al., 2008). This SNP does lead to a decrease in the trafficking of BDNF to secretory vesicles and the subsequent activity-dependent release of BDNF (Egan et al., 2003; Chen et al., 2004, 2005). As the hippocampus is target of many cortical and subcortical projections, the decreased levels of BDNF could in part be due to decreased BDNF secretion from afferent inputs to the hippocampus. In recent reports, the BDNF Val66Met SNP has also been shown to impact trafficking of BDNF mRNA to dendritic processes where it can be locally transcribed (Chiaruttini et al., 2009). Reduced transport and local translation of BDNF mRNA in $\mathrm{BDNF}^{\text {Met/Met }}$ mice may also contribute to the lower protein expression observed in the hippocampus. Such effects may contribute to previously described alterations in dendritic complexity of hippocampal neurons of $\mathrm{BDNF}^{\mathrm{Met} / \mathrm{Met}}$ mice (Chen et al., 2006). However, further studies are required to fully understand the basis of this marked decrease in basal hippocampal BDNF protein levels.
$\mathrm{BDNF}^{\mathrm{Met} / \mathrm{Met}}$ mice had significantly fewer surviving newly born cells in the $\mathrm{DG}$ compared with $\mathrm{BDNF}^{\mathrm{Val} / \mathrm{Val}}$ mice. Disruptions in neurogenesis have been reliably linked with the development of anxiety-like behavior and antidepressant response in animal models of anxiety and depressivelike disorders (Santarelli et al., 2003). Here we demonstrate that cell survival is impaired in the $\mathrm{DG}$ of $\mathrm{BDNF}^{\mathrm{Met} / \mathrm{Met}}$ mice, an effect that is correlated with their development of anxiety-like behaviors. We further show that SSRI's can significantly potentiate the survival of cells in the DG of $\mathrm{BDNF}^{\text {Met/Met }}$ mice. These data could suggest that SSRIinduced augmentation in newly born cell survival may not be critical for the behavioral effects of antidepressants in $\mathrm{BDNF}^{\text {Met/Met }}$ mice. Alternatively, animals that have had a chronic blunting in the survival of adult born cells throughout life may simply not benefit from the modest yet significant increase in cell survival (eg the degree to which cell survival increased may have been simply insufficient).

We have shown that the BDNF Val66Met SNP leads to decreased trafficking of BDNF into secretory granules (Chen et al., 2004, 2005) and thus a reduction in the activitydependent release of BDNF (Egan et al., 2003; Chen et al., 2005, 2006). In BDNF Val66Met mice, we anticipate that the reduced activity-dependent release of BDNF onto immature cells and thus a decrease in critical trophic support during the process of cellular differentiation is the critical underlying factor leading to decreased survival of newly born cells. Such findings are consistent with previously published reports demonstrating that the genetic or pharmacological ablation of BDNF results in decreased adult neurogenesis within the hippocampus (Sairanen et al., 2005; Chan et al., 2008; Choi et al., 2009), with specific effects on the maturation and survival of newly born neurons and the selective expression and activation of the BDNF receptor TrkB on postmitotic neuroblasts.

We uncovered significant impairments in synaptic plasticity in the dentate gyrus of $\mathrm{BDNF}^{\text {Met/Met }}$ mice, under both basal conditions and following chronic fluoxetine treatment. We have recently described significant effects of this SNP on synaptic transmission and plasticity at the CA3-CA1 synapse (Ninan et al., 2010). To our knowledge, these are the first studies to identify impairments in synaptic plasticity resulting from the BDNF Val66Met SNP in the DG. On the basis of our observations, SSRI-induced augmentations in LTP were completely blocked in $\mathrm{BDNF}^{\text {Met/Met }}$ mice an effect that parallels the failure of these mice to show behavioral benefits of antidepressant treatment. Despite the rescue of neurogenesis to control levels, fluoxetine failed to reverse LTP impairment in $\mathrm{BDNF}^{\text {Met/Met }}$ mice. These results suggest that fluoxetine affects plasticity by mechanisms other than neurogenesis. The lack of effect of fluoxetine on BDNF levels or a potential alteration of synaptic function might be responsible for fluoxetine-resistant LTP impairment in BDNF $^{\text {Met/Met }}$ mice (Colino and Malenka, 1993; Ninan et al., 2010). BDNF has reliably been shown to be a significant promoter of synaptic excitability and LTP within the hippocampus (Minichiello, 2009) and the loss of TrkB from newborn neurons in this region significantly impact LTP (Bergami et al., 2008). We hypothesize that the observed effects of $\mathrm{BDNF}^{\text {Met/Met }}$ on synaptic functions are in large part due to a general 
decrease in the availability of BDNF in $\mathrm{BDNF}^{\mathrm{Met} / \mathrm{Met}}$ mice as a result of impairments in activity dependent BDNF secretion. However, given the potential impact of this SNP on trafficking of BDNF mRNA to dendrites, we cannot rule out the potential role of alterations in postsynaptic BDNF expression as a contributing factor to this effect.

In conclusion, these findings provide some of the first mechanistic links between the BDNF Val66Met SNP and the development of SSRI-resistant anxiety-like behaviors. Thus, these mice may provide a useful model system to test novel therapeutic strategies to rescue anxiety and depressive-like symptoms that are unresponsive to standard drug regimens. Furthermore, such a model system may be important for understanding the mechanisms underlying treatment response to common antidepressant and anxiolytic drugs and the contribution of genetic variation to treatment outcome.

\section{ACKNOWLEDGEMENTS}

This work was supported by the Sackler Institute (K.G.B.), DeWitt-Wallace Fund of the New York Community Trust (F.S.L), Irma T. Hirschl/Monique Weill-Caulier Trust (F.S.L.), International Mental Health Research Organization (F.S.L.), Burroughs Wellcome Foundation (FSL), Pritzker Consortiun (F.S.L), Brain \& Behavior Research FoundationNARSAD (I.N., K.G.B., F.S.L), and National Institutes of Health grants HD055177 (S.S.P.), NS21072 (M.V.C), MH060478 (K.G.B.), NS052819 (F.S.L.), and MH088814 (F.S.L.).

\section{DISCLOSURE}

None of the authors report biomedical financial interests or potential conflicts of interest. The authors declare that over the past year, FSL has received compensation as a consultant for Ono Pharmaceuticals.

\section{REFERENCES}

Adachi M, Barrot M, Autry AE, Theobald D, Monteggia LM (2008). Selective loss of brain-derived neurotrophic factor in the dentate gyrus attenuates antidepressant efficacy. Biol Psychiatry 63: 642-649.

Barde YA, Davies AM, Johnson JE, Lindsay RM, Thoenen $\mathrm{H}$ (1987). Brain derived neurotrophic factor. Prog Brain Res 71: 185-189.

Bath KG, Mandairon N, Jing D, Rajagopal R, Kapoor R, Chen ZY et al. (2008). Variant brain-derived neurotrophic factor (Val66Met) alters adult olfactory bulb neurogenesis and spontaneous olfactory discrimination. J Neurosci 28: 2383-2393.

Bergami M, Berninger B, Canossa M (2009). Conditional deletion of TrkB alters adult hippocampal neurogenesis and anxietyrelated behavior. Commun Integr Biol 2: 14-16.

Bergami M, Rimondini R, Santi S, Blum R, Gotz M, Canossa M (2008). Deletion of TrkB in adult progenitors alters newborn neuron integration into hippocampal circuits and increases anxiety-like behavior. Proc Natl Acad Sci USA 105: 15570-15575.

Castren E (2004). Neurotrophic effects of antidepressant drugs. Curr Opin Pharmacol 4: 58-64.

Chan JP, Cordeira J, Calderon GA, Iyer LK, Rios M (2008). Depletion of central BDNF in mice impedes terminal differentiation of new granule neurons in the adult hippocampus. Mol Cell Neurosci 39: 372-383.
Chao MV (2003). Neurotrophins and their receptors: a convergence point for many signalling pathways. Nat Rev Neurosci 4: 299-309.

Chen ZY, Ieraci A, Teng H, Dall H, Meng CX, Herrera DG et al. (2005). Sortilin controls intracellular sorting of brain-derived neurotrophic factor to the regulated secretory pathway. J Neurosci 25: 6156-6166.

Chen ZY, Jing D, Bath KG, Ieraci A, Khan T, Siao CJ et al. (2006). Genetic variant BDNF (Val66Met) polymorphism alters anxietyrelated behavior. Science 314: 140-143.

Chen ZY, Patel PD, Sant G, Meng CX, Teng KK, Hempstead BL et al. (2004). Variant brain-derived neurotrophic factor (BDNF) (Met66) alters the intracellular trafficking and activity-dependent secretion of wild-type BDNF in neurosecretory cells and cortical neurons. J Neurosci 24: 4401-4411.

Chiaruttini C, Vicario A, Li Z, Baj G, Braiuca P, Wu Y et al. (2009). Dendritic trafficking of BDNF mRNA is mediated by translin and blocked by the G196A (Val66Met) mutation. Proc Natl Acad Sci USA 106: 16481-16486.

Choi SH, Li Y, Parada LF, Sisodia SS (2009). Regulation of hippocampal progenitor cell survival, proliferation and dendritic development by BDNF. Mol Neurodegener 4: 52.

Colino A, Malenka RC (1993). Mechanisms underlying induction of long-term potentiation in rat medial and lateral perforant paths in vitro. J Neurophysiol 69: 1150-1159.

Donovan MH, Yamaguchi M, Eisch AJ (2008). Dynamic expression of TrkB receptor protein on proliferating and maturing cells in the adult mouse dentate gyrus. Hippocampus 18: $435-439$.

Dulwala SC, Hen R (2005). Recent advances in animal models of chronic antidepression effects: the novelty induced hypophagia test. Neurosci Biobehav Rev 29: 771-783.

Dulawa SC, Holick KA, Gundersen B, Hen R (2004). Effects of chronic fluoxetine in animal models of anxiety and depression. Neuropsychopharmacology 29: 1321-1330.

Duman RS, Monteggia LM (2006). A neurotrophic model for stress-related mood disorders. Biol Psychiatry 59: 1116-1127.

Egan MF, Kojima M, Callicott JH, Goldberg TE, Kolachana BS, Bertolino A et al. (2003). The BDNF val66met polymorphism affects activity-dependent secretion of BDNF and human memory and hippocampal function. Cell 112: 257-269.

Figurov A, Pozzo-Miller LD, Olafsson P, Wang T, Lu B (1996). Regulation of synaptic responses to high-frequency stimulation and LTP by neurotrophins in the hippocampus. Nature 381: 706-709.

Gao X, Chen J (2009). Conditional knockout of brain-derived neurotrophic factor in the hippocampus increases death of adult-born immature neurons following traumatic brain injury. J Neurotrauma 26: 1325-1335.

Gatt JM, Nemeroff CB, Dobson-Stone C, Paul RH, Bryant RA, Schofield PR et al. (2009). Interactions between BDNF Val66Met polymorphism and early life stress predict brain and arousal pathways to syndromal depression and anxiety. Mol Psychiatry 14: 681-695.

Huang EJ, Reichardt LF (2001). Neurotrophins: roles in neuronal development and function. Annu Rev Neurosci 24: 677-736.

Hwang JP, Tsai SJ, Hong CJ, Yang CH, Lirng JF, Yang YM (2006). The Val66Met polymorphism of the brain-derived neurotrophicfactor gene is associated with geriatric depression. Neurobiol Aging 27: 1834-1837.

Iga J, Ueno S, Yamauchi K, Numata S, Tayoshi-Shibuya S, Kinouchi S et al. (2007). The Val66Met polymorphism of the brain-derived neurotrophic factor gene is associated with psychotic feature and suicidal behavior in Japanese major depressive patients. Am J Med Genet B Neuropsychiatr Genet 144B: 1003-1006. 
Klein R, Parada LF, Coulier F, Barbacid M (1989). trkB, a novel tyrosine protein kinase receptor expressed during mouse neural development. EMBO J 8: 3701-3709.

Li Y, Luikart BW, Birnbaum S, Chen J, Kwon CH, Kernie SG et al. (2008). TrkB regulates hippocampal neurogenesis and governs sensitivity to antidepressive treatment. Neuron 59: 399-412.

Lyons WE, Mamounas LA, Ricaurte GA, Coppola V, Reid SW, Bora $\mathrm{SH}$ et al. (1999). Brain-derived neurotrophic factor-deficient mice develop aggressiveness and hyperphagia in conjunction with brain serotonergic abnormalities. Proc Natl Acad Sci USA 96: 15239-15244.

Manji HK, Quiroz JA, Sporn J, Payne JL, Denicoff K, Gray AN et al. (2003). Enhancing neuronal plasticity and cellular resilience to develop novel, improved therapeutics for difficult-to-treat depression. Biol Psychiatry 53: 707-742.

McNaughton BL (1980). Evidence for two physiologically distinct perforant pathways to the fascia dentata. Brain Res 199: 1-19.

Minichiello L (2009). TrkB signalling pathways in LTP and learning. Nat Rev Neurosci 10: 850-860.

Monteggia LM, Barrot M, Powell CM, Berton O, Galanis V, Gemelli $\mathrm{T}$ et al. (2004). Essential role of brain-derived neurotrophic factor in adult hippocampal function. Proc Natl Acad Sci USA 101: 10827-10832.

Musazzi L, Cattaneo A, Tardito D, Barbon A, Gennarelli M, Barlati $S$ et al. (2009). Early raise of BDNF in hippocampus suggests induction of posttranscriptional mechanisms by antidepressants. BMC Neurosci 10: 48.

Ninan I, Bath KG, Dagar K, Perez-Castro R, Plummer MR, Lee FS et al. (2010). The BDNF Val66Met polymorphism impairs NMDA receptor-dependent synaptic plasticity in the hippocampus. J Neurosci 30: 8866-8870.

Okada T, Hashimoto R, Numakawa T, Iijima Y, Kosuga A, Tatsumi $\mathrm{M}$ et al. (2006). A complex polymorphic region in the brainderived neurotrophic factor (BDNF) gene confers susceptibility to bipolar disorder and affects transcriptional activity. Mol Psychiatry 11: 695-703.

Russo-Neustadt AA, Chen MJ (2005). Brain-derived neurotrophic factor and antidepressant activity. Curr Pharm Des 11: 1495-1510.

Sahay A, Hen R (2007). Adult hippocampal neurogenesis in depression. Nat Neurosci 10: 1110-1115.

Sairanen M, Lucas G, Ernfors P, Castren M, Castren E (2005). Brain-derived neurotrophic factor and antidepressant drugs have different but coordinated effects on neuronal turnover, proliferation, and survival in the adult dentate gyrus. $J$ Neurosci 25: 1089-1094.

Santarelli L, Saxe M, Gross C, Surget A, Battaglia F, Dulawa S et al. (2003). Requirement of hippocampal neurogenesis for the behavioral effects of antidepressants. Science 301: 805-809.

Sarchiapone M, Carli V, Roy A, Iacoviello L, Cuomo C, Latella MC et al. (2008). Association of polymorphism (Val66Met) of brain-derived neurotrophic factor with suicide attempts in depressed patients. Neuropsychobiology 57: 139-145.

Saxe MD, Battaglia F, Wang JW, Malleret G, David DJ, Monckton JE et al. (2006). Ablation of hippocampal neurogenesis impairs contextual fear conditioning and synaptic plasticity in the dentate gyrus. Proc Natl Acad Sci USA 103: 17501-17506.

Scharfman H, Goodman J, Macleod A, Phani S, Antonelli C, Croll S (2005). Increased neurogenesis and the ectopic granule cells after intrahippocampal BDNF infusion in adult rats. Exp Neurol 192: 348-356.

Schmidt HD, Duman RS (2007). The role of neurotrophic factors in adult hippocampal neurogenesis, antidepressant treatments and animal models of depressive-like behavior. Behav Pharmacol 18: 391-418.

Shirayama Y, Chen AC, Nakagawa S, Russell DS, Duman RS (2002). Brain-derived neurotrophic factor produces antidepressant effects in behavioral models of depression. J Neurosci 22: 3251-3261.

Siuciak JA, Lewis DR, Wiegand SJ, Lindsay RM (1997). Antidepressant-like effect of brain-derived neurotrophic factor (BDNF). Pharmacol Biochem Behav 56: 131-137.

Snyder JS, Kee N, Wojtowicz JM (2001). Effects of adult neurogenesis on synaptic plasticity in the rat dentate gyrus. J Neurophysiol 85: 2423-2431.

Soliman F, Glatt CE, Bath KG, Levita L, Jones RM, Pattwell SS et al. (2010). A genetic variant BDNF polymorphism alters extinction learning in both mouse and human. Science 327: 863-866.

Tsai SJ, Hong CJ, Liou YJ (2010). Effects of BDNF polymorphisms on antidepressant action. Psychiatry Investig 7: 236-242.

Verhagen M, van der Meij A, van Deurzen PA, Janzing JG, AriasVasquez A, Buitelaar JK et al. (2010). Meta-analysis of the BDNF Val66Met polymorphism in major depressive disorder: effects of gender and ethnicity. Mol Psychiatry 15: 260-271.

Wang JW, David DJ, Monckton JE, Battaglia F, Hen R (2008). Chronic fluoxetine stimulates maturation and synaptic plasticity of adult-born hippocampal granule cells. J Neurosci 28: $1374-1384$.

Supplementary Information accompanies the paper on the Neuropsychopharmacology website (http://www.nature.com/npp) 